\title{
TEACHING WRITING IN A COLLEGE OF ENGINEERING*
}

\author{
Thomas M. Sawyer, University of Michigan
}

It is an honor and a privilege to be invited to speak to you this evening. When Professor Alred telephoned me to ask if I would speak to the American Business Communication Association meeting I was enormously flattered. I was so flattered that I neglected to point out to Professor Alred that if he had scoured the entire United States he could not have found anyone with less knowledge of business, or of the communication of business information, than myself. I am the sort of fellow who always thought an escrow was a sort of French writing table and a debenture was a kind of ice box in which one placed one's equity for fear the assets would melt and become liquid. But I had the great good fortune to marry the daughter of an Iowa banker, and shortly after we were married she caught me surreptitiously counting on my fingers as I tried valiantly to balance my checkbook. She promptly took it away from me, placed me on a niggardly allowance, and we have thrived ever since.

But Professor Alred also told me over the phone that in addition to all the prosperous business people who would be attending this conference there would be a large number of well-known, learned, and prestigious teachers of English in attendance. "You do teach writing, don't you?" he inquired. And I admitted that that is really all I have done for the past 32 years. But I couldn't bring myself to confess to him that I have taken just four college-level English courses as a studentfreshman composition, a junior year course in literary criticism, a senior year course in creative writing, and a graduate survey course in drama.

I make this confession about my lack of expertise in the world of business and in the world of English in the hopes that you will forgive any glaring errors in my remarks and attribute them to simple ignorance on my part.

Perhaps it might be of interest to you if I told you how I happened to become, without any training, a teacher of writing, especially of scientific and technical writing. Second, I think you might be interested in a brief description of the department which employs me; after all, any outfit which employs someone like me must be peculiar, though I think they would prefer the word "unique." Third, I would like to tell how we go about teaching both undergraduate students and practicing engineers, technical writers and editors, and practicing teachers of writing.

First, how did I become a teacher of writing? I want to discuss this because it seems to me that many, if not all, teachers of business communication, or of technical writing, got there by chance. It was sheer chance that thrust me into a career as an English teacher. In 1939 I was a senior at Kenyon College in Gambier, Ohio, a lovely little village five miles from anywhere, and a tiny, Oxfordlike college of 300 all male students. I was a Biology major, and a good one. Even today if you hand me the embalmed carcass of a cat, I can show you the greater trochanter of the humerus in a trice. I had a stable, in small bottles of course, of red-eyed and white-eyed fruitflies which I bred assiduously.

Since there were no female students at Kenyon College and no females in the village of Gambier except the wives of Kenyon faculty or the daughter of the local greengrocer, after a long day of slicing frog livers into tissue-thin slices for microscope slides I expended my excess youthful energies in Thespian activities, largely because the local ladies were the only source of actresses and many of the play scripts called upon one of the student actors to clasp, even to kiss, one of these ladies. I distinctly recall my Political Science professor announcing to the class, while leering at me, "If some people don't keep their hands off my wife, they're going to flunk this course!"

It was this excess energy which led me to take a course in creative writing with John Crowe Ransom. I knew nothing at all about him except that he seemed to enjoy considerable status as the editor of the Kenyon Review and some of the newspapers and news magazines seemed to have heard of him.

There were only about six of us in this creative writing class - me and five non-Biologists, such as; Robie Macauley, now fiction editor of Playboy magazine; Peter Taylor, whose short stories were later to appear in New Yorker; and Robert Lowell, who has since made a name for himself as a poet. In Ransom's seminar I too wrote poetry-for the simple, practical reason that it took less time and paper to produce two or three lyrics than it did to devise a 20- or 30-page short story.

*The after dinner address at the American Business Communication Association Midwest Regional Conference, University of WisconsinMilwaukee, Wisconsin. A pril 22, 1977. 
But alas! I graduated from this idyllic ivory tower in June 1939 and headed into the world of business, which in those days seemed strangely unreceptive to lyric poets, amateur actors, or even frog liver slicers. I ended up in Toledo, Ohio, working 12 hours a day for fifty cents an hour as a machinist turning out copper commutators for electric motors in a factory which would probably remind many of you of a scene from one of Charles Dickens's novels. I'm afraid that that experience has contaminated my attitude towards Toledo, Ohio, ever since.

After a full year of this seamy sort of life, I received a letter from the Alumni Secretary of Kenyon College telling me that a preparatory school in Honolulu, Hawaii, was looking for a Biology teacher. Would I care to apply?

Would I care to apply! With visions of palm trees, white sands, and dusky hula girls, I dashed off a letter of application immediately. Clearly I needed some letters of recommendation. My Biology professor was an obvious choice. The President of Kenyon College was another. You must remember that the college was small enough that every student knew the President.

But two letters, like a two-legged stool, felt unbalanced. I needed a third. So I asked our academic star, John Crowe Ransom, for a letter as well.

Months passed in Dickensian gloom. Then one day I received a cablegram-my very first cablegram! (Come to think of it, the only cablegram I have ever received.) It said: "Offer you a job teaching English. Nine hundred dollars a year."

I was flabbergasted! I was a Biologist. Well, yes I was temporarily a machinist, but I thought of myself as a Biologist. What were they doing offering me a job teaching English? I didn't know anything about that.

But anything was better than making commutators in Toledo, Ohio. I promptly cabled back: "I accept. But why English?"

It turned out that Headmaster Stone of Iolani School in Honolulu had already hired a Biology teacher by the time my application arrived. But in the meantime a hot-blooded young English teacher had made a pass at the Headmaster's blonde and nubile daughter and had been abruptly and untimely dismissed. With the start of the school year rapidly approaching, the Headmaster had riffled through the applications on his desk looking for a replacement, had stumbled across Professor Ransom's generous letter of recommendation in my behalf, and decided to take a chance on me.
You may well remark upon the paucity of my training for such a position-especially in light of the fact that the students I was about to faceall boys-were evenly distributed among those from Japanese, Chinese, Portuguese, Korean, Hawaiian, and Haole (the Hawaiian word for "stranger" or white man) family backgrounds. Indeed I taught every last thing I knew in the first fifteen minutes of the first class. I had nothing left to say-not for the rest of the hour, not for the rest of the day, not for the rest' of the week, not for the rest of the year.

But Headmaster Stone had been a missionary in China and he was, when I knew him, a Major in the Chaplain Corps of the U.S. Army. He know something about the teaching of the English language to boys whose native language was not English. And he knew something about training untrained teachers like myself to teach such boys. $\mathrm{He}$ required me to turn in to him each week a detailed outline of what I planned to do the coming week in each of my five classes of 25 boys. And each week I was expected to assign, receive, read, mark-up in detail, and grade a composition from each and every student. Thus he expected me to grade 125 compositions every week. And he asked me to submit sample batches of compositions to him at frequent intervals so that he could check up on how well I was reading and marking up all those papers.

As you will appreciate, I saw a great deal less of those palm trees, white sands, and dusky hula girls than I had anticipated. This was the only instruction I have ever received in how to teach writing. Headmaster Stone taught me an invaluable lesson. I had, and have, never worked so hard in my life. But after 32 years I still believe that it is essential to plan out, and on paper for all to see, what you hope to accomplish in every class meeting. And I still believe that it is essential that the students write a composition every single week. My senior Engineering students write a paper or deliver a speech every single week during the term, but, fortunately, I have fewer than the $125 \mathrm{I}$ had in Honolulu.

Pearl Harbor Day closed all the schools in Hawaii so I became in rapid succession: a Red Cross First Aid Instructor; a teacher of Speech and Drama back at Kenyon College again (perhaps because I had kissed so many faculty wives); an ambulance driver with the American Field Service attached to the British 14th Army in Burma, the 8th Army in Italy, and the 21st Army Group in Belgium and Holland. In 1945 I was back in Ann Arbor, Michigan, 
once more a machinist as I had been in Toledo, hoping, despite the lack of G.I. Bill benefits, to work my way through graduate school while working on the night shift as a punch-press operator for a ball bearing company in Ann Arbor. And once again I became a teacher entirely by chance.

As I was preparing to register as a graduate student in Speech, I was suddenly tapped on the shoulder by the Chairman of the English Department of the College of Engineering who asked if I would like to teach freshman speech and freshman composition to engineering students. Although I had been a punch-press operator for only a week and a half, I had already decided that I preferred pushing a pencil to pushing a greasy strip of steel plate. So I again said yes.

The English Department of the College of Engineering changed its name to Humanities Department in 1968, but it still remains a peculiar and unique institution. On the Ann Arbor campus of the University of Michigan, with 33,000 students, 17 different schools and colleges, and 155 different graduate degree programs, the Humanities Department with a professorial staff of 24 is the one and only purely service department-that is, a department which has no students of its own. The University also has a large, graduate English Department with a professorial staff of about 70 which serves the rest of the campus. Only three other universities that I know of have similar arrangements. The Engineering Colleges of the Universities of Washington and Virginia and the College of Agriculture at the University of Minnesota also mantain separate departments to teach their students literature and composition.

Why should the College of Engineering at Michigan have a separate department? Like my own teaching career it is partly due to chance. Originally the University had a single English Department to serve all students. But in 1889 Professor Fred Newton Scott was brought to Ann Arbor and he combined great vigor with a great interest in teaching writing. In 1903 he helped to establish a Department of Rhetoric, concentrating on teaching writing rather than literature. Professor Scott also brought to Ann Arbor an expert in engineering report writing, Professor J. Raleigh Nelson, who became the first chairman of what was popularly "Engineering English" in 1908. Unfortunately, Professor Scott retired in 1930 and the Department of Rhetoric was merged with the Department of English. From the point of view of the College of Engineering that date may perhaps mark the beginning of the subsidence in the level of the writing ability of students-nonengineering students, that is.

But as a matter of fact when I joined the Engineering English Department in 1945 it was difficult to detect any differences between it and the larger, more prestigious English Department across the campus, except that it was smaller and offered fewer courses. Although the College didn't object if the Department offered some undergraduate survey courses in literature, it considered our principal function to be teaching students how to write. Since the engineering faculty didn't know much about teaching writing, they left it up to us. However, most of our faculty didn't know much about teaching writing either. Most of the professorial staff were graduates of English departments and consequently had taken about as many courses in teaching writing as I had-none. J. Raleigh Nelson had retired; only one professor was left who taught report writing and he was near retirement and not very popular with the students anyway. The staff consisted of 7 Professors, 4 Instructors finishing their Ph.D.'s in literature, and 17 graduate student Teaching Fellows like myself because the College had a booming enrollment of returning G.I. veterans.

So we taught writing the way everyone else did, and most English departments still do-we taught freshman composition. First year engineers took two terms of composition and one term of speech for six hours of credit. Upperclassman took two more two-hour courses in literature-a total package of 10 credit hours.

If the department had continued on this course I believe that the prospects for our continued existence as a separate department would now be dismal indeed. We were doing nothing that could not have been done just as well by the English Department across the campus. Of course we argued that we did it better because we had a special affinity for undergraduate students, but today as graduate enrollments in English plummet, the department across the campus is rapidly developing the same affinity-although it seems to be a painful process.

Fortunately we did not continue on the same course and today we can argue that we really do provide a unique and special service. Several factors led us to change our program.

First, when our lone report writing teacher retired some of his younger colleagues were drafted to take over this senior-level elective course. Because they had no preconceptions about how it should be taught because they had no training in such 
teaching, they approached it fresh, consulted with the engineering faculty about what should be required, discovered to their surprise that these engineers simply wanted engineering reports written in such a way that any educated laymen could read and understand them, and found that as educated laymen themselves, the course was interesting to teach. W. Earl Britton was one of these younger men, and some of you may have read, among his other articles, his argument "The Trouble With Technical Writing is Freshman Composition" in the book, The Teaching of Technical Writing published by the National Council of Teachers of English. As Britton learned, senior engineering students, unlike freshmen, had a great deal of interesting information, and, again unlike freshmen, they were trying to convey it to an educated layman-their English teacher. Freshmen are always writing to people who know more than they do. Britton became so interested in this communication problem that he organized a summer conference course for engineers from industry, and the course is now in its 20 th year and has on occasion enrolled as many as 90 participants.

Second, in 1957 Sputnik went into orbit and shortly thereafter so did engineering research in the United States. One of the major centers for research in radar and infrared scanning devices was Willow Run Laboratories at the University of Michigan. They began to produce a flood of reports of experiments and of new technical developments and needed a number of technical editors to help with these manuscripts. So some of us were offered part-time editorial work in these laboratories. We found that it was fun trying to help such people as Emmett Leith, who developed the new technique of holography, explain what it was he was doing. Thus several more of us became interested in scientific and technical writing.

But the most important factor was the establishment in 1965 of a special committee in the College of Engineering charged with shortening the entire curriculum to enable a student to graduate in four years, rather than four and a half or five. Every department, including Engineering English, was represented on this committee and we were given carte blanche. "Forget about tradition," we were told, "propose the sorts and arrangements of courses you think would be ideal." A golden opportunity!

So we thought hard about it. We all disliked freshman composition, and so did the students. It was drudgery for both student and teacher. We all thought that six hours of Great Books- the Iliad, Oedipus, the Platonic Dialogues, Dante, Chaucer, Shakespeare, The Federalist Papers, and the like-would be better for freshman who knew so little of our cultural heritage and who were too young to have acquired sufficient information or experience to have anything to write about that was worth reading. Moreover, Great Books would be much more fun to teach.

Rather naturally each English teacher had his own literary specialty that he wanted to teach, so a required course in literature for upperclassman was proposed.

But what were we going to do about writing and speaking? The engineering faculty would certainly never agree to a program devoted entirely to literature and without training in communication.

Then a very simple and sensible idea occurred to us. Why not require all seniors to take a course in writing and speaking? Those of us who had acquired some experience in teaching technical writing and in doing scientific editing honestly enjoyed such work. Why not simply turn our traditional arrangement of courses upside down? Great Books for freshman, composition for seniors, and literature in between. No one else we knew of had an arrangement like this, but why not take a chance?

This is what we proposed to the College and they accepted it. When the new curriculum was adopted in 1967 we became the only department in the entire College to be allocated more hours, rather than fewer -12 hours as opposed to our original ten. And once the new curriculum was approved, we argued that our new program was so superior to our old one that we deserved a new name to signalize this reincarnation. The University Regents agreed and in 1968 rechristened us the Humanities Department of the College of Engineering.

Frankly I think our program is one that every English department should adopt. Courses in communication should be offered when the student needs them, and that is when he is a senior and has acquired a body of knowledge about his chosen specialty and is about to go forth and try to apply it. He will need to communicate to others what he knows, and he will need to persuade them to use the esoteric skills he now possesses. If he cannot communicate that knowledge, if he cannot persuade people that his skills are applicable, he will indeed be helpless.

How do we try to meet this student's needs? Since I just finished the final examination in my own Scientific and Technical Communication 
course last Wednesday night, perhaps a description of this examination may be illuminating.

This term I had 33 seniors: Mechanical Engineers, Chemical Engineers, Civil Engineers, Nuclear Engineers, Metallurgical Engineers, Electrical Engineers, Computer Engineers, and Naval Architects. We often enroll students from other colleges as well, such as Nursing, Pharmacy, Public Health. This term I had a Zoologist and a major in Natural Resources. The list of topics they were writing and talking about is too long to recite here, but here are some examples:

Powder Diffraction: Debyr-Scherrer Technique for Compound Identification

Electromagnetic Pulse Effects on Aircraft:

Analysis of Surface Fields on Models

Icebreaker Hull for the Great Lakes: A Pre-

liminary Design

Essential Hypertension: Renin-Sodium Profiling as a Basis for Treatment

Pulsed TEA $\mathrm{CO}_{2}$ Lasers: Design and Principles of Construction

The examination these students faced was really a very simple one. Each student submitted two copies of his final written report, one to be read by an engineer from an industry in Ann Arbor-such as Mr. William Amey, Control Systems Specialist for the Bechtel Power Corporation-the other to be read by a technical writer or editor from an industry in Ann Arbor-such as Mr. James McGraw, Technical Editor for Manufacturing Data Systems. Each of these examiners also came in the evening to listen to the students give a 10-minute public lecture on the same topic. There they, and the other members of the audience, could ask the students any questions they wished. These public lectures were also videotaped and in a week or so, after the students have had an opportunity to see their lectures themselves, they will be broadcast over Ann Arbor's Cable TV system for the whole city to see and hear.

It is the two examiners-Mr. Amey and Mr. McGraw, for example-who will decide what the students' final grades should be. Since they are still studying the students' written reports, I don't yet know how my students made out, but I can assure you that I am in the same nervous sweat the students are.

As you can probably guess, the whole of the term is spent in practice for this final test. The students write parts and pieces of their final reports and distribute them to the other students for critical comments. It becomes pretty obvious that if the Zoologist and the Civil Engineer can't understand pulsed TEA $\mathrm{CO}_{2}$ lasers, the Nuclear Engineer better work hard on his explanation so that it will be clear to Mr. Amey and Mr. McGraw. My function is to help, and for this reason I think it's only fair that Mr. Amey and Mr. McGraw evaluate me too and submit a grade for me to my Departmental Chairman and my Dean. Last December, for 41 students, the examiners awarded an overall average grade of 3.2 , or just better than a $B$ for the whole group. Eight students got $A$ 's from both examiners, and 15 got an $A$ from one and a $B$ from the other. The Dean hasn't yet told me what grade I got.

I am sure that you are all aware of C. P. Snow's argument that there are now two distinct culturesthe culture of science and technology and the culture of literature and the humanities. I am doing my best to help scientists and engineers make themselves comprehensible to people on the other side.

But since I am speaking to the American Business Communication Association it occurs to me that there may be a third culture-the culture of business. And business is relying more and more on the computers that my engineers produce. You can program a computer to do a lot of interesting things, even to write a manuscript for you. Here is a sample of what Lexar Company of Los Angeles can get the computer to write if it programs it to choose a random batch of words and link them together following grammatical rules. See if this doesn't almost sound as if it meant something:

Parallel organizational capability may always

be compared with a continuous search for opti-

mal interaction; often the product configura-

tion encompasses any phased requirements. A

specific example magnifies the importance of

inherent infrastructure constraints.

But here is a sample of business writing which may, only may, have been written by a human being. It is a notice my wife received from a local department store, and I read it in full:

Any holder of this consumer credit contract is subject to all claims and defenses which the debtor could assert against the seller of goods or services obtained pursuant hereto or with the proceeds hereof. Recovery hereunder by the debtor shall not exceed amounts paid by the debtor hereunder.

I am sure that you all know what that means, and I would very much appreciate it if you would assist the author thereof in making himself comprehensible to us less fortunate creatures who come from an alien culture. 